\title{
Anisakid nematodes prevalence in Chilean hake (Merluccius gayi gayi) commercialized in the city of Talca, Chile
}

\author{
Alex Silva ${ }^{1,2}$, María Teresa Rojas ${ }^{1}$, Pamela Morales ${ }^{1}$, Tamara Muñoz ${ }^{1}$ \& Álvaro Machuca ${ }^{1}$ \\ ${ }^{1}$ Escuela de Medicina Veterinaria, Facultad de Recursos Naturales y Medicina Veterinaria \\ Universidad Santo Tomás, Chile \\ ${ }^{2}$ Seremi de Salud, Ministerio de Salud, Chile \\ Corresponding author: Álvaro Machuca (alvaromachucana@santotomas.cl)
}

\begin{abstract}
The main objective of this work was to determine the presence of anisakid larvae in fresh Chilean hake Merluccius gayi gayi coming from the coastal area near the city of Talca, Chile, commonly commercialized by a regional fish supply center located in the same city. Flesh and viscera of 214 fish were analyzed via direct observation, and the prevalence of parasitism was calculated. The results showed a prevalence of $100 \%$ and $24.3 \%$ in viscera and flesh, respectively. Morphologic characterization of 138 randomly selected larvae was performed via diaphanization technique, observing 106 larvae of Anisakis spp., 13 larvae of Pseudoterranova spp. and 19 nematodes classified as "unidentified." All larvae here analyzed were viable based on the spontaneous movement ability of parasites. Overall, the high prevalence of fish infected with Anisakidae larvae highlights the importance of taking early intervention actions in order to prevent the occurrence of anisakidosis in the human Chilean population; particularly critical given the current culinary preference for raw fish dishes such as ceviche and sushi, which poses a public health issue.
\end{abstract}

Keywords: Anisakis; Pseudoterranova; Chilean hake (Merluccius gayi gayi); nematodes; anisakid; prevalence

Anisakidosis disease is caused by any member Anisakidae (Nematoda), a foodborne parasitic zoonosis (Nieuwenhuizen, 2016). In countries such as Japan, Spain, Mexico, Canada and the United States, anisakidosis is considered an endemic disease. In South America, Chile is the country that shows a high prevalence of anisakids in fish (Torres et al., 2014), becoming it into a country very susceptible to present cases of anisakiasis in humans. Anisakidae includes 24 genera, three of them with importance in public health: Anisakis, Contracaecum and Pseudoterranova (Jofré et al., 2008). Fish are an intermediate host of the L3 infective larvae, which migrate through the digestive wall reaching abdominal organs such as liver, ventral or dorsal muscles, and surrounding connective tissue. Humans are an accidental host of larval stage L3, which in many cases causes gastrointestinal or allergic manifestations (Baird et al., 2014; Nieuwenhuizen \& Lopata, 2014; Moneo et al., 2017). These parasites have been found in several fish species, including the Chilean hake (Merluccius gayi gayi) (Jofré et al.,
2008). This fish species is well distributed along the Chilean coast and is one of the most highly consumed fish of the Chilean people (Quezada \& Dresdner, 2014).

In recent times, the consumption habits of the Chilean population have changed. The incorporation of "foreign" dishes such as ceviche, sushi or sashimi, based on raw or undercooked fish, has become a public health issue due to a higher risk of the presence of viable anisakid parasites in food. Based on the fact that Chile is a major consumer of hake, several studies on anisakid parasitosis have been carried out. GeorgeNascimento (1996) described the populations of parasites in Chilean hake from three major fishing areas of central Chile describing high prevalence (>53\%) for Anisakis spp., and low prevalence for Pseudoterranova decipiens and Contracaecum spp. (average 26 and 9\%, respectively).

In contrast, another study published by Torres $e t$ al. (2000) showed a prevalence of 5.9\% of Anisakis spp., and $23.5 \%$ of Pseudoterranova spp. in commerciallized M. gayi gayi in the city of Valdivia, Chile. A

Corresponding editor: Leonardo Abitia 
study by Oliva \& Ballón (2002) reported a prevalence of over $80 \%$ of Anisakis simplex observed in Chilean hake. A study conducted in the extreme south of Chile described the southern hake (Merluccius australis) parasitosis, reporting prevalence that averaged $90 \%$ for Anisakis spp., 49\% for Contracaecum spp. and 12\% for Pseudoterranova decipiens (George-Nascimento \& Arancibia, 1994). Madrid et al. (2016) showed the existence of an increasing prevalence of anisakid parasites among years, since in 2006 was $32.2 \%$ compared to $72.5 \%$ in 2012 in Merluccius spp. commercialized in the city of Concepción, which they had a size and weight on average $40 \mathrm{~cm}$ and $500 \mathrm{~g}$, respectively. Scientific data demonstrate the existence of a high risk of human infection by anisakid parasites upon consumption of fish commonly commercialized in Chile. Nevertheless, no studies exist on the prevalence of these parasites in fish destined to human consumption in Talca, Chile. The main objective of this work was to determine the prevalence of nematodes belonging to the Anisakidae in flesh and abdominal organs of fresh Chilean hake coming from the coastal area near Talca, Chile, and likewise to determine the current risk of transmission of this foodborne disease to the population in this city.

In this study, 214 fish were obtained from the coastal area near Talca, Chile, which were commercialized by a regional fish supply center located in the same city. The average weight of fish analyzed was $341.1 \mathrm{~g}$. The individual fish in the study were selected according to a probabilistic sampling assuming the presence of different sizes and weights of fish. The analyses were performed over three consecutive days. Initially, 56 fish were analyzed. A longitudinal cut from the operculum to the tail was performed in order to reach the coelomic cavity and visceral surfaces to obtain larvae. Numerous deep cuts were made to reach the epaxial and hypaxial muscle, and fillets of $5 \mathrm{~mm}$ thickness were gotten. The same procedure was performed in all fish in the study on the second and the third days with 53 and 105 fish, respectively. The prevalence was defined as the number of infected fish with at least one larva divided by the total fish examined (Margolis et al., 1982). For the identification of anisakid nematodes, a representative sample of L3 larvae was taken using a sample size calculation for finite populations, according to Naing et al. (2006). After obtaining the parasites, larvae viability was determined based on spontaneous movement in a Petri dish filled with distilled water. The genus of each larva was determined through the diaphanization technique, which allows the recognition of internal nematode organs (Torres et al., 2014). Following the guidelines used by Rello et al. (2004) and Quiazon et al. (2008), the digestive apparatus and physical characteristics such as size, thickness and color were observed to determinate the classification of anisakid nematodes. Due to technical problems on sample preparations, some individual fish were not identified within a genus; therefore, they were assigned as "unidentified."

Of the 214 fish analyzed in this study, all presented a high number of nematodes (an average of 20 parasites per fish), located mainly on the surface of abdominal organs such as liver, gut, gonads and also free in the coelomic cavity (Figs. 1a-b), which indicates a $100 \%$ prevalence in these organs (Table 1). Nematodes were easily observed within the coelomic cavity immediately after the ventral dissection of the fish. In addition, 52 fish presented L3 larvae embedded in the muscle (Fig. 1c, Table 1), most of them found in hypaxial muscle tissue, corresponding to a prevalence of $24.3 \%$. Afterward, $138 \mathrm{~L} 3$ larvae from different fishes were used for identification analysis. According to the morphologic characteristics of Anisakidae, three different groups were determined: Anisakis spp., Pseudoterranova spp. and "unidentified." Thirteen larvae (9.42\%) were identified as genus Pseudoterranova based on anatomical characteristics such as size, color, appendant glands and form of the tail in its rear end; and 106 larvae (76.81\%) as Anisakis, which were identified by the digestive apparatus (due to ventricle form) (Fig. 1d). A group of 19 larvae $(13.77 \%)$ were classified as "unidentified" due to damage during sampling. From all samples analyzed, $100 \%$ of larvae presented vigorous movement in distilled water and therefore were considered as viable larvae.

It is well known that the increased risk of zoonosis is constituted by the consumption of raw or undercooked fish muscle. In the present study, we found a prevalence of $24.3 \%$ of L3 larvae in the muscle of fresh Merluccius gayi gayi. The prevalence in the muscle of Merluccius spp. has been reported in other geographic regions of Chile. In Valdivia, Chile, Torres et al. (2014) reported the prevalence of Anisakis spp. and Pseudoterranova spp. in the muscle of Merluccius australis showing 8.7 and $4.8 \%$, respectively. Madrid et al. (2016) studied the prevalence in the muscle of Merluccius spp. reporting prevalence of 32.2 and $72.5 \%$ in samples obtained in 2006 and 2012, respectively. Both groups of authors performed a technique called "candling" for larvae identification in muscle. Many factors may contribute to the variation in results between studies such as observation technique used: the depth of cuts or the time elapsed since the evisceration of fish, because it is demonstrated that anisakid larvae migrate to the muscle after the host death (Deardorff et al., 1984). Although we performed 

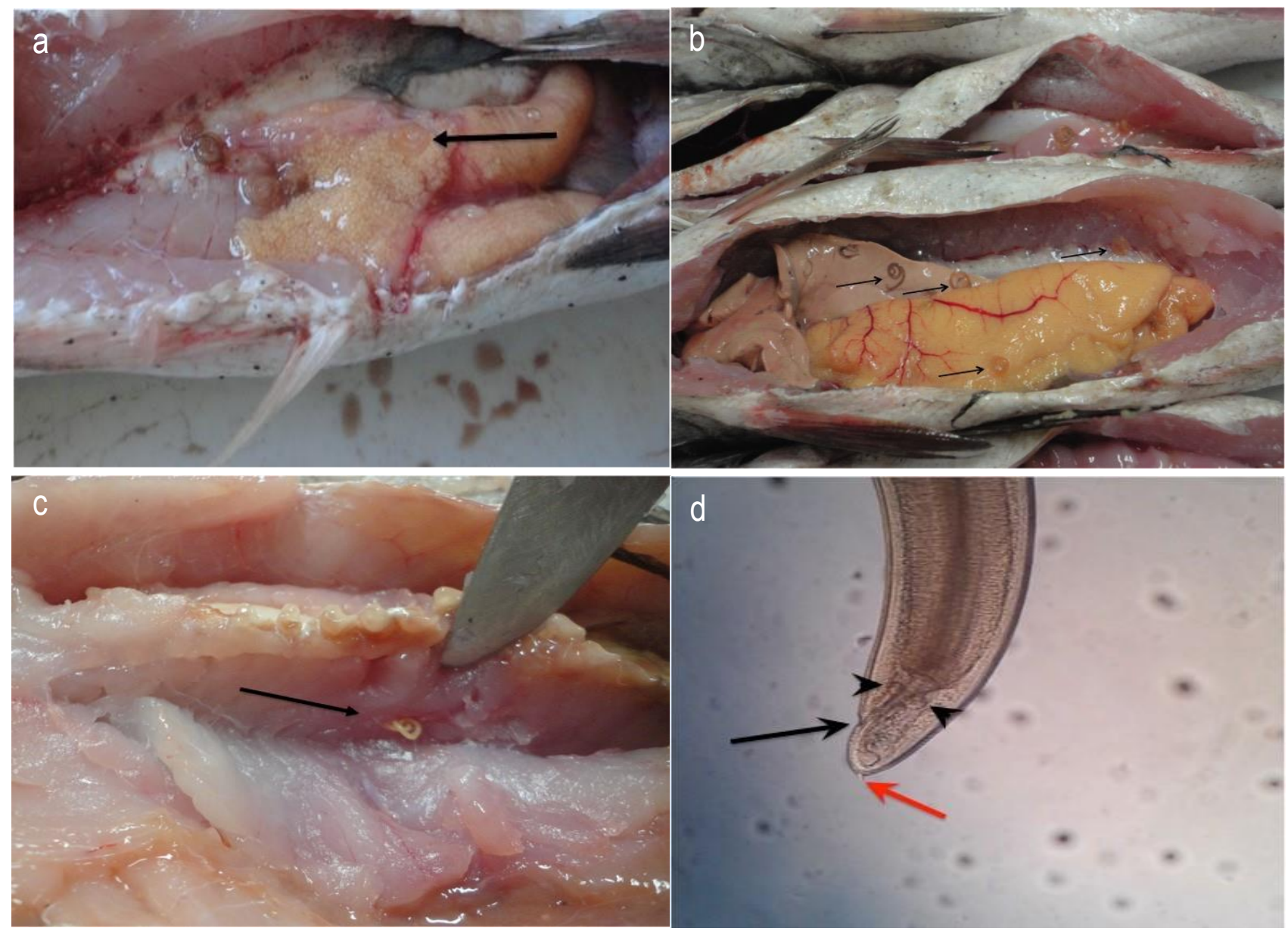

Figure 1. Members of Anisakidae in Chilean hake Merluccius gayi gayi. a-b) Several larvae in the visceral surfaces (liver, gonads), c) the arrow shows a parasite embedded in fish muscle, d) posterior end of larva (L3) of anisakid. The photograph shows the mucron (red arrow), anal pore (black arrow) and anal glands (arrowheads).

Table 1. Summary of prevalence in analyzed Chilean hake.

\begin{tabular}{lcccc}
\hline Location of parasite & $\begin{array}{c}\text { Parasitized } \\
\text { fish }\end{array}$ & $\begin{array}{c}\text { Fish without } \\
\text { parasites }\end{array}$ & $\mathrm{n}$ & $\begin{array}{c}\text { Prevalence } \\
(\%)\end{array}$ \\
\hline Flesh & 52 & 162 & 214 & 24.3 \\
Abdominal organs & 214 & 0 & 214 & 100 \\
\hline
\end{tabular}

thin and deep cuts throughout the hypaxial and epaxial musculature of the fish and only analyzed macroscopically these slices, in our study, we could identify embedded parasites mainly in hypaxial muscle tissue, similar to the data observed by Madrid et al. (2016).

Using the diaphanization technique, we observed 106 larvae (76.81\%) belonging to the genus Anisakis and 13 larvae $(9.42 \%)$ from genus Pseudoterranova. These data are similar to those of George-Nascimento (1996) and Torres et al. (2014), which describe a lower prevalence of the Pseudoterranova genus compared to Anisakis spp. However, more updated studies are nee- ded with samples obtained along the coast of Chile to confirm these differences.

A recent study showed the prevalence of Anisakis spp. in Brama australis in three southern Chilean localities: $16.8 \%$ in Lebu, $10.6 \%$ in Calbuco and 6.7\% in Punta Arenas (Oliva et al., 2016). Several data demonstrate the importance of this nematode parasite in public health and the risk of infection due to this seafood-borne disease worldwide, which affects many different fish species destined for human consumption such as: Chilean jack mackerel (Trachurus murphyi) (George-Nascimento et al., 1983), sardines (Sardina pilchardus) and anchovies (Engraulis encrasicolus) 
(Serracca et al., 2014; Cavallero et al., 2015; MolinaFernández et al., 2015), Atlantic mackerel (Scomber scombrus) (Pekmezci, 2014), lamprey (Petromyzon marinus) (Bao et al., 2013), golden kingklip (Genypterus blacodes) and snoek (Thyrsites atun) (Torres et al., 2014). Respecting the salmon farmed industry, Marty (2008) described the presence of anisakid larvae in the viscera of a farmed Atlantic salmon (Salmo salar), however, the prevalence described was very low $(0.11 \%)$ probably because of artificial diets which also contain medications designated for salmon (Sepúlveda et al., 2004).

Nowadays, the eating habits of people have changed, with an increase in the consumption of raw marine fish (Bao et al., 2017) such as sushi or ceviche. From 1976 to 2005, at least 28 people have been diagnosed with anisakidosis, from which 12 were by consumption of ceviche (Madrid et al., 2016). Afterward, at least 5 cases of anisakidosis have been reported in Chile (Celestino et al., 2007; Weitzel et al., 2015). Torres-Frenzel \& Torres (2014) described the presence of viable larvae in commercial hake ceviche in southern Chile, showing a prevalence of 16.7 and $7.1 \%$ in examined portions from two cities, Valdivia and Niebla, respectively, highlighting the relevance of this emerging fishborne zoonotic disease.

This study demonstrates the high risk of foodborne infection with anisakid parasites for the Talca city population, mainly through dishes prepared with raw local fish such as ceviche, sushi or sashimi. It is also important to ensure early evisceration of fish followed by optimal storage temperatures under article No323 of Chilean Food Sanitary Regulations, which state that all fish-derived products commercialized for human consumption must be free of parasites and their cyst (MINSAL, 2019). Further investigation of the presence of these parasites in dishes prepared in the city of Talca with fish extracted from the coast near the city, as well as to characterize the migration of L3 larvae at different storage times and temperatures is needed.

\section{REFERENCES}

Baird, F.J., Gasser, R.B., Jabbar, A. \& Lopata, A.L. 2014. Foodborne anisakiasis and allergy. Molecular and Cellular Probes, 28(4): 167-174.

Bao, M., Garci, M.E., Antonio, J.M. \& Pascual, S. 2013. First report of Anisakis simplex (Nematoda, Anisakidae) in the sea lamprey (Petromyzon marinus). Food Control, 33(1): 81-86.

Bao, M., Strachan, N.J.C., Hastie, L.C., Mackenzie, K., Seton, H.C. \& Pierce, G.J. 2017. Employing visual inspection and Magnetic Resonance Imaging to inves- tigate Anisakis simplex s.l. infection in herring viscera. Food Control, 75: 40-47.

Cavallero, S., Magnabosco, C., Civettini, M., Boffo, L., Mingarelli, G., Buratti, P., Giovanardi, O., Fortuna, C.M. \& Arcangeli, G. 2015. Survey of Anisakis sp. and Hysterothylacium sp. in sardines and anchovies from the North Adriatic Sea. International Journal of Food Microbiology, 200: 18-21.

Celestino, C., Hirano, T., Sáenz, R., Vargas, L. \& Gobelet, J. 2007. Anisakiasis: a preventable culinary attack on the gastrointestinal tract. Endoscopy, 39: E312.

Deardorff, T., Raybourne, R. \& Desowitz, R. 1984. Behavior and viability of third-stage larvae of Terranova sp. (Type HA) and Anisakis simplex (Type I) under coolant conditions. Journal of Food Protection, 47: 4952.

George-Nascimento, M. 1996. Populations and assemblages of parasites in hake, Merluccius gayi, from the southeastern Pacific Ocean: stock implications. Journal of Fish Biology, 48: 557-568.

George-Nascimento, M. \& Arancibia, H. 1994. La fauna parasitaria y la morfometría de la merluza austral Merluccius australis (Hutton) y su aporte a la distinción de unidades de stock. Biología Pesquera, 23: 3147.

George-Nascimento, M., Carvajal, J.G. \& Alcaíno, H. 1983. Occurrence of Anisakis sp. larvae in the Chilean jack mackerel, Trachurus murphyi Nichols 1920. Revista Chilena de Historia Natural, 56: 31-37.

Jofré, L., Neira, P., Noemí, I. \& Cerva, J. 2008. Pseudoterranovosis y sushi. Revista Chilena de Infectología, 25(3): 200-206.

Madrid, V., Rivera, A. \& Fernández, I. 2016. Prevalencia de larvas de Anisakidae (Nematoda: Ascaridoidae) en musculatura de merluza chilena, Merluccius sp. comercializada en Concepción, Chile, en distintos periodos. Parasitología Latinoamericana, 65(4): 27-31.

Margolis, L., Esch, G.W., Holmes, J.C., Kuris, A.M. \& Schad, G.A. 1982. The use of ecological terms in parasitology (Report of an ad-hoc Committee of the American Society of Parasitologists). Journal of Parasitology, 68(1): 131-133.

Marty, G.D. 2008 Anisakid larva in the viscera of a farmed Atlantic salmon (Salmo salar). Aquaculture, 279(1-4): 209-210.

Ministerio de Salud (MINSAL). 2019. Reglamento sanitario de los alimentos. Gobierno de Chile. Documento $\mathrm{N}^{\circ}$ 977/96. [https://dipol.minsal.cl/wpcontent/uploads/2019/04/DECRETO_977_96_2019. pdf]. Reviewed: May 24, 2019.

Molina-Fernández, D., Malagón, D., Gómez-Mateos, M., Benítez, R., Martin-Sánchez, J. \& Adroher, F.J. 2015. Fishing area and fish size as risk factors of Anisakis infection in sardines (Sardina pilchardus) from Iberian 
waters, southwestern Europe. International Journal of Food Microbiology, 203: 27-34.

Moneo, I., Carballeda-Sangiao, N. \& González-Muñoz, M. 2017. New perspectives on the diagnosis of allergy to Anisakis spp. Current Allergy and Asthma Reports, 17(5): 27.

Naing, L., Winn, T. \& Rusli, B.N. 2006. Practical issues in calculating the sample size for prevalence studies. Archives of Orofacial Sciences, 1: 9-14.

Nieuwenhuizen, N.E. 2016. Anisakis - immunology of a foodborne parasitosis. Parasite Immunology, 38(9): 548-557.

Nieuwenhuizen, N.E. \& Lopata, A.L. 2014. Allergic reactions to Anisakis found in fish. Current Allergy and Asthma Reports, 14(8): 455.

Oliva, M.E. \& Ballón, I. 2002. Metazoan parasites of the Chilean hake Merluccius gayi gayi as a tool for stock discrimination. Fisheries Research, 56: 313-320.

Oliva, M.E., Espinola, J.F. \& Nacari, L.A. 2016. Metazoan parasites of Brama australis from southern Chile: a tool for stock discrimination? Journal of Fish Biology, 88(3): 1143-1148.

Pekmezci, G.Z. 2014. Occurrence of Anisakis simplex sensu stricto in imported Atlantic mackerel (Scomber scombrus) represents a risk for Turkish consumers. International Journal of Food Microbiology, 185: 6468.

Quezada, F. \& Dresdner, J. 2014. The behavior of hake prices in Chile: is the world market leading? Latin American Journal of Aquatic Research, 42(5): 10871098.

Quiazon, K.M., Yoshinaga, T., Ogawa, K. \& Yukami, R. 2008. Morphological differences between larvae and in vitro-cultured adults of Anisakis simplex (sensu stricto) and Anisakis pegreffii (Nematoda: Anisakidae). Parasitology International, 57(4): 483-489.
Rello, F., Adroher, F. \& Valero, A. 2004. Anisákidos parásitos de peces comerciales. Riesgos asociados a la salud pública. Anales de la Real Academia de Ciencias Veterinarias de Andalucía Oriental, 17(1): 173-197.

Sepúlveda, F., Marín, S. \& Carvajal, J. 2004. Metazoan parasites in wild fish and farmed salmon from aquaculture sites in southern Chile. Aquaculture, 235: 89-100.

Serracca, L., Battistini, R., Rossini, I., Carducci, A., Verani, M., Prearo, M., Tomei, L., De Montis, G. \& Ercolini, C. 2014. Food safety considerations in relation to Anisakis pegreffii in anchovies (Engraulis encrasicolus) and sardines (Sardina pilchardus) fished off the Ligurian Coast (Cinque Terre National Park, NW Mediterranean). International Journal of Food Microbiology, 190: 79-83.

Torres, P., Moya, R. \& Lamilla, J. 2000. Nemátodos anisákidos de interés en salud pública en peces comercializados en Valdivia, Chile. Archivos de Medicina Veterinaria, 32(1): 107-113.

Torres, P., Puga, S., Castillo, L., Lamilla, J. \& Miranda, J. 2014. Helmintos, myxozoos y microsporidios en músculos de peces comercializados frescos y su importancia como riesgo potencial para la salud humana en la ciudad de Valdivia, Chile. Archivos de Medicina Veterinaria, 46(1): 83-92.

Torres-Frenzel, P. \& Torres, P. 2014. Anisakid parasites in commercial hake ceviche in southern Chile. Journal of Food Protection, 77(7): 1237-1240.

Weitzel, T., Sugiyama, H., Yamasaki, H., Ramirez, C., Rosas, R. \& Mercado, R. 2015. Human infections with Pseudoterranova cattani nematodes, Chile. Emerging Infectious Diseases, 21(10): 1874-1875. 